\title{
Identification and Characterization of Natural Sweeteners from "Trembesi" Fruit Pulp (Albizia saman)
}

\author{
Sri Winarti ${ }^{1 *}$, Siska Mardiana ${ }^{2}$ \\ ${ }^{1}$ Food Technology Departement, Faculty of Engineering UPN "Veteran" Jawa Timur, Indonesia \\ ${ }^{2}$ Graduated of Food Technology Departement, Faculty of Engineering UPN "Veteran" Jawa Timur, Indonesia
}

\begin{abstract}
Research has been carried out on the process of natural sweeteners from the pulp of the "trembesi" fruit. The purpose of this study was to identify the types of sugar (fructose, glucose, sucrose) and to determine the effect of extraction temperature on the characteristics of natural sweeteners from "trembesi" pulp. This study used a simple completely randomized design (CRD) with extraction temperature treatments $\left(60^{\circ} \mathrm{C}, 70^{\circ} \mathrm{C}, 80^{\circ} \mathrm{C}, 90^{\circ} \mathrm{C}\right.$ and $\left.100^{\circ} \mathrm{C}\right)$. The data obtained were analyzed using the Analysis of Variance (ANOVA) method, if there was a significant difference between treatments, it was continued with Duncan's Test (DMRT). The results of the research, it is known that the pulp of the tamarind fruit contains a total of $53.65 \%$ sugar; fructose $20.55 \%$; glucose $12.77 \%$; sucrose $18.21 \%$; water content $25.739 \%$; ash $2.771 \%$; $1.226 \%$ protein; fat $7.028 \%$; and carbohydrates $63.196 \%$. The best treatment is the extraction temperature of $100^{\circ} \mathrm{C}$; which produces natural sweeteners with the following characteristics: viscosity $11.71 \mathrm{cp}$; and sensories of viscosity 4.1 . Total sugar in natural sweetener from pulp of the "trembesi" fruit $73.36 \%$; fructose $26.40 \%$; glucose $12.11 \%$; and $25.4 \%$ sucrose.
\end{abstract}

Keywords: CRD, Trembesi, ANOVA

\section{Introduction}

"Trembesi" plants are known by several names in English such as Rain Tree, Monkey Pod, East Indian Walnut, Saman Tree, and False Powder Puff [1]. The "trembesi" plant has long been known by the people of Indonesia. This plant has many parts that can be used. However, the use of "trembesi" fruit is still very limited. Lack of knowledge about the content in the "trembesi" plant so that people only use it as firewood and shade. Trembesi fruit is a long straight, slightly curved pod with a length of between $10-20 \mathrm{~cm}$ with a width of 1.5 $2 \mathrm{~cm}$ and a thickness of about $0.6 \mathrm{~cm}$. The fruit is black and the pulp of the fruit is reddish brown and sticky when ripe, there are round seeds about $5 \mathrm{~mm}$ long and dark brown in color embedded in the flesh. "Trembesi" fruit has a sweet taste and a sticky texture [2]. It is suspected that the "trembesi" fruit contains sugar which can be used as a natural sweetener.

Sweetener is one of the food ingredients whose needs are always increasing every year. Until now, Indonesia still has to import sweeteners, especially cane sugar to meet domestic needs.

Based on the projections of the Agricultural Data and Information System Centre of the Ministry of Agriculture, domestic sugar consumption in 2017 is projected to reach 5.07 million tons while production is only 2.47 million tons. As a result, the sugar balance experienced a deficit of 2.6 million tons. Sugar consumption is projected to continue to increase to 5.26 million tons in 2021 while production will only reach 2.48 million tons, resulting in a deficit of 2.78 million tons [3]. So, it is necessary to develop alternative sweeteners from other plants that can be used to meet the needs of these sweeteners.

Sweeteners are additives that are often added and used for the purposes of processed food products, industry, as well as beverages and food. Sweeteners are food additives that are added to food or beverages to create a sweet taste [4]. Natural sweeteners usually come from plants. Some natural ingredients that have been used as sweeteners include sugar cane, dates, corn, coconut sap and stevia. However, the use of "trembesi" fruit pulp as a sweetener has never existed, therefore an exploration of the tamarind fruit pulp as an alternative natural sweetener has been carried out.

Natural sweeteners are obtained by extraction. Extraction is carried out to obtain the desired component by separating the component from a material which is the source of the component [5]. Therefore, extraction is carried out on the pulp of the "trembesi" fruit to obtain the sugar components present in the fruit. Several factors that can affect the extraction are drying, material reduction, temperature, and type of solvent.

According to [6], sugar is a simple carbohydrate because it can be dissolved in water and directly

\footnotetext{
* Corresponding author : sriwinarti.tp@upnjatim.ac.id
} 
absorbed by the body to be converted into energy. In general, sugars are divided into two, namely monosaccharides and disaccharides.

As the name implies, mono which means one, it is formed from one sugar molecule. Which includes monosaccharides are glucose, fructose, galactose. Unlike monosaccharides, disaccharides are made up of two sugar molecules. Disaccharides include sucrose, lactose, and maltose.

\section{Research Method}

The materials used in this study were ripe, brownishblack "trembesi" fruit with reddish-brown pulp obtained from the campus yard of the Pembangunan National University "Veteran", Jawa Timur. The chemicals used for analysis were distilled water, kjeldahl tablets, concentrated $\mathrm{H}_{2} \mathrm{SO}_{4}, \mathrm{NaOH}$, boric acid, methyl red, $\mathrm{HCl}$, ptreleum benzene, anthrone reagent, 99.5\% glucose standard solution, $99.0 \%$ fructose standard solution, and standard solution sucrose $99.5 \%$.

The equipment used in this research is a vacuum evaporator, viscometer, stopwatch and a set of HPLC/HPLC waters e2695 which is equipped with a refractive index detector, and a color reader.

The design used was a completely randomized design (CRD) with 1 factor consisting of 5 levels and 4 replications. The data were analyzed statistically by ANOVA test, then continued with Duncan's New Multiple Range Test (DMRT) at 5\% significance level.

\subsection{Identification of "Trembesi" Fruit Pulp Content}

The pulp of "trembesi" fruit was analyzed for its chemical composition including water content, ash content, protein, fat, carbohydrates, total sugar and types of sugar. Moisture content and ash content were analyzed using the oven method, protein content using the Kjeldahl method [7], fat content using the Soxhlet method, carbohydrate content using the by difference method, total sugar using the Anthrone method, and types of sugar analyzed using the High-Performance Liquid Chromatography (HPLC) by injecting 20 samples and standard solutions (glucose, fructose, and sucrose) into HPLC with a run time of 20 minutes.

\subsection{The Process of Making Natural Sweeteners "Trembesi" Fruit Pulp}

Trembesi fruit pulp extraction was done by crushing the trembesi fruit pulp using a blender. The pulp extraction process was carried out using water at temperatures of $60^{\circ} \mathrm{C}, 70^{\circ} \mathrm{C}, 80^{\circ} \mathrm{C}, 90^{\circ} \mathrm{C}$ and $100^{\circ} \mathrm{C}$. The extract of the "trembesi" fruit pulp was then evaporated using a rotary evaporator at a temperature of $65^{\circ} \mathrm{C}$ and a pressure of $150 \mathrm{mBar}$ for 40 minutes.

\section{Results and Discussion}

\subsection{Proximate analysis and types of Natural Sweeteners in pulp of "trembesi" fruit}

The results of proximate analysis and types of sugar in the raw material for the pulp of "trembesi" fruit which include water content, ash content, protein, fat, and carbohydrates, total sugar and types of sugar can be seen in Table 1.

Table 1. Proximate and sugar in pulp of "trembesi" fruit.

\begin{tabular}{lc}
\hline Compound & Content $(\%)$ \\
\hline Water & $25,739 \pm 0,51$ \\
Ash & $2,771 \pm 0,43$ \\
Protein & $1,226 \pm 0,44$ \\
Fat & $7,028 \pm 0,52$ \\
Carbohydrate & $63,196 \pm 0,47$ \\
Sugar Total & $53,65 \pm 0,41$ \\
Fructose & $20,55 \pm 0,41$ \\
Glucose & $12,77 \pm 0,46$ \\
Sucrose & $18,21 \pm 0,54$ \\
\hline
\end{tabular}

Total sugar in the pulp of the "trembesi" fruit pulp was $53.65 \%$ and the types of sugar identified using the HPLC reactive index detector were fructose, glucose, and sucrose $20.55 \%, 12.77 \%$, and $18.21 \%$, respectively.

\subsection{Viscosity of Natural Sweeteners}

The viscosity of the sweetener extract from the pulp of the "trembesi" fruit was measured objectively using a viscosimeter and subjectively using the human senses (sensory evaluation), and compared the correlations.

Table 2. Viscocity of natural sweeteners from pulp of "trembesi" fruit.

\begin{tabular}{ccc}
\hline $\begin{array}{c}\text { Extraction } \\
\text { Temperature }\left({ }^{0} \mathrm{C}\right)\end{array}$ & $\begin{array}{c}\text { Viscosity } \\
(\mathrm{c} . P s)\end{array}$ & $\begin{array}{c}\text { Sensories of } \\
\text { Viscosity }\end{array}$ \\
\hline 60 & $6.30 \pm 0.32^{\mathrm{a}}$ & $2.95 \pm 0.39^{\mathrm{a}}$ \\
70 & $6.43 \pm 0.49^{\mathrm{a}}$ & $2.85 \pm 0.58^{\mathrm{a}}$ \\
80 & $7.12 \pm 0.71^{\mathrm{a}}$ & $3.20 \pm 0.67^{\mathrm{a}}$ \\
90 & $9.22 \pm 0.44^{\mathrm{b}}$ & $3.95 \pm 0.63^{\mathrm{b}}$ \\
100 & $11.71 \pm 0.24^{\mathrm{b}}$ & $410 \pm 0.47^{\mathrm{b}}$ \\
\hline
\end{tabular}

Notes: Values accompanied by the same letter indicate that they are not significantly different.

Table 2 shows that the higher the extraction temperature, the higher the viscosity value of the natural sweetener of the "trembesi" fruit pulp. This is because increasing the extraction temperature can increase the rate of transfer of components other than water extracted from the pulp cells of the "trembesi" fruit so that the dissolved solids that are extracted also increase and cause the viscosity of the product to increase. This statement is supported by [8], which states that the higher the extraction temperature, the faster the molecular movement. [9] also stated that the increase in temperature and extraction time can cause an increase in the levels of extracted components. This is because the increase in temperature and extraction time causes the extraction rate to be higher. [10], stated that viscosity is related to total dissolved solids. The higher the total solids concentration, the higher the viscosity. 


\subsection{Corelation Viscosity of Natural Sweeteners}

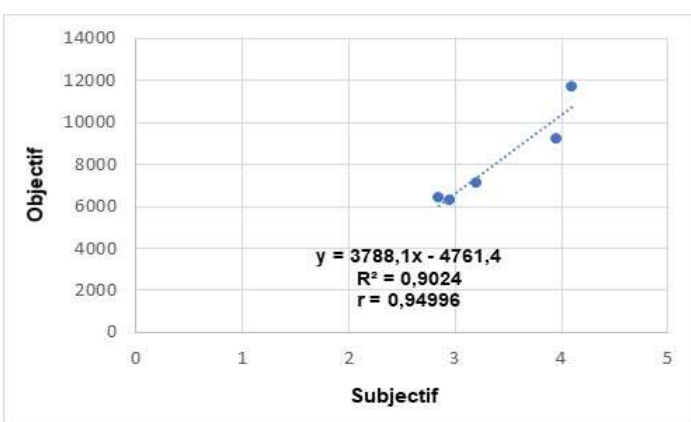

Fig. 1. Corelation Viscosity of Natural Sweeteners

Figure 1 shows that there is a very strong relationship between the results of subjective viscosity analysis performed by organoleptic tests and objective viscosity analysis by measuring viscosity using a viscometer. This is indicated by the results of the linear regression equation $\mathrm{y}=3788.1 \mathrm{x}-4761.4$ with the value of the correlation coefficient of linear regression is $\mathrm{r}=$ 0.94996 and the coefficient of determination $\mathrm{R} 2=$ 0.9024 . The correlation results show a positive value so that it is known that the results of subjective and objective viscosity analysis of natural sweeteners of "trembesi" fruit pulp have a unidirectional relationship. This statement is supported by [9] which states that the correlation coefficient is a value that indicates the strength or absence of a linear relationship between two variables.

\subsection{Total and Type of Sugar in Natural Sweeteners}

The results of the analysis of total sugar and types of sugar in natural sweeteners from "trembesi" fruit pulp from the best extraction temperature $\left(100^{\circ} \mathrm{C}\right)$ can be seen in Table 3. The results of the analysis of total sugar in natural sweeteners of "trembesi" fruit pulp were $73.36 \%$, fructose was $16.4 \%$, glucose was $12 \%$, and sucrose was $25.4 \%$. According to SNI 01-6237-2000, the sugar content in brown sugar is at least $65 \%$ (quality I) or $60 \%$ (quality II). The sugar content obtained in this study has met the minimum standard because the natural sweetener of the "trembesi" fruit pulp has sugar content above $60 \%$ (quality II) and $65 \%$ (quality I).

Table 3. Total and Type of Sugar in Natural Sweeteners from pulp of "trembesi" fruit.

\begin{tabular}{lc}
\hline Compound & Content $(\%)$ \\
\hline Total Sugar & $73.36 \pm 0,06$ \\
Fructose & $26.40 \pm 0,08$ \\
Glucose & $12.11 \pm 0,12$ \\
Sucrose & $25.04 \pm 0,09$ \\
\hline
\end{tabular}

Research by [11], natural sweetener of randu honey contains $40,099 \%$ fructose and $27.31 \%$ glucose. Based on the results of the sugar composition of the natural sweetener of the "trembesi" fruit pulp, liquid brown sugar of siwalan sap, and the natural sweetener of Randu honey, it shows that each natural sweetener contains a different sugar composition, because the sugar content of each ingredient is different. This is in accordance with the statement of [12], which states that each component of food ingredients varies greatly in type and amount so that they will form different structures, textures, tastes, aromas, colors and nutritional content.

\section{Conclusion}

"Trembesi" fruit pulp contains a total sugar of 53.65\%, fructose $20.55 \%$, glucose $12.77 \%$, sucrose $18.21 \%$, water content $25.739 \%$, ash content $2.771 \%$, protein $1.226 \%$, fat $7.028 \%$ and carbohydrates $63.196 \%$. Extraction temperature affects the characteristics and total sugar content of natural sweeteners from the pulp of the tamarind fruit. The best extraction temperature is $100^{\circ} \mathrm{C}$, which produces natural sweeteners with total sugar characteristics of $73.36 \%$; fructose $26.4 \%$; glucose $12 \%$, and sucrose $25.4 \%$.

\section{References}

1. Staples, G. W. dan Elevitch, C. R. Samanea saman (rain tree), ver. 2.1. In C.R. Elvitch (ed.), Species Profiles for Pasific Island Agroforestry, Permanent Agriculture Resources (PAR): Holualoa, Hawaii (2006).

2. Purwati, T. Samanea saman (Jacq.) Merr. Germplasm Resources Information Network. United States Department of Agriculture (2010).

3. Badan Pusat Statistik (BPS). Expenditure for Indonesian Population Consumption by Province. (2018).

4. Cahyadi, W. Analysis and Health Aspects of Food Additives. (PT Bumi Aksara : Jakarta, 2005)

5. Andarwulan, N., F. Kusnandar, and D. Herawati. Food Analysis. (Dian Rakyat, Jakarta, 2011).

6. Darwin, P. Enjoy Sugar Without Fear. (Sinar Ilmu. Yogyakarta, 2013).

7. AOAC. Official Methods of Analysis. Association of Official Analytical Chemist. (Washingtons DC, 2005).

8. Setyowati, W.A.E. Effect of Extraction Method on Antioxidant Activity of Durian Fruit Peel (Durio zibethinus Murr) Petruk Variety. Prosiding National. (Universitas Negri Semarang, 2013).

9. Satriyanto, B., Widjanarko, S.B., and Yunianta. Journal of Agricultural Technology.13. 3 (2012).

10. Lini. Effect of Addition of Xanthan Gum on Physicochemical and Organoleptic Properties of Sweet Corn Soybean Extract. (Prosiding Nasional, Faculty of Agricultural Technology Katolik Widya Mandala University, Surabaya, 2010).

11. Ratnayani, K., N.M.A. Dwi Adhi S., and I.G.A.M.A.S. Gitadewi. Determination of glucose and fructose levels in randu honey and longan honey by high performance liquid chromatography method. Journal of Chemistry 2, 2, (Departement of Chemistry FMIPA, Udayana University, 2008). 
12. Faridah, A., Yuliana., R. Holinesti. Science of Food Ingredients Sourced from Vegetables. (Gifari

Prasetama, Jakarta, 2013). 